\title{
Global rules for global health: why we need an independent, impartial WHO
}

\section{Citation}

Sridhar, D., J. Frenk, L. Gostin, and S. Moon. 2014. “Global Rules for Global Health: Why We Need an Independent, Impartial WHO." BMJ 348 (jun18 17) (June 18): g3841-g3841. doi:10.1136/ bmj.g3841.

\section{Published Version}

doi:10.1136/bmj.g3841

\section{Permanent link}

http://nrs.harvard.edu/urn-3:HUL.InstRepos:37260724

\section{Terms of Use}

This article was downloaded from Harvard University's DASH repository, and is made available under the terms and conditions applicable to Other Posted Material, as set forth at http:// nrs.harvard.edu/urn-3:HUL.InstRepos:dash.current.terms-of-use\#LAA

\section{Share Your Story}

The Harvard community has made this article openly available.

Please share how this access benefits you. Submit a story.

Accessibility 
2014

\section{Global Rules for Global Health: Why We Need An Independent, Impartial WHO}

Devi Sridhar

University of Edinburgh

Julio Frenk

Harvard School of Public Health

Lawrence O. Gostin

Georgetown University Law Center, gostin@law.georgetown.edu

Suerie Moon

Harvard School of Public Health

This paper can be downloaded free of charge from:

http://scholarship.law.georgetown.edu/facpub/1349

http://ssrn.com/abstract $=2456735$

Devi Sridhar, Julio Frenk, Lawrence O. Gostin, \& Suerie Moon, Global Rules for Global Health: Why We Need An Independent, Impartial WHO, BMJ (June 18, 2014), http://www.bmj.com/ content/348/bmj.g3841 


\title{
Global rules for global health: why we need an independent, impartial WHO
}

Devi Sridhar and colleagues argue that WHO's unique political legitimacy makes it essential to achieving international action on global health and call for governments to re-establish guaranteed core funding

\author{
Devi Sridhar senior lecturer ${ }^{12}$, J Frenk dean ${ }^{3}$, L Gostin professor ${ }^{4}, \mathrm{~S}_{\text {Moon lecturer }}^{3}$ \\ ${ }^{1}$ Centre for Population Health Sciences, Edinburgh University, Edinburgh EH8 9LD, UK; ${ }^{2}$ Blavatnik School of Government, University of Oxford, \\ Oxford, UK; ${ }^{3}$ Harvard Global Health Institute, Harvard School of Public Health, Boston, MA, USA; ${ }^{4} \mathrm{O}$ Neill Institute for Global and National Health \\ Law, Georgetown University, Washington, DC, USA
}

Over the past few years the World Health Organization (WHO) has been undergoing substantial reform. The immediate trigger was a budget crisis in 2010 that spurred massive staff cuts. But at a more fundamental level, deeper systematic changes in global health governance have made reform imperative. ${ }^{1}$ Though WHO reform draws relatively little attention outside diplomatic circles in Geneva, at stake are critical concerns that will affect public health everywhere.

The essential role of WHO is most often appreciated when outbreaks of infectious disease cross borders, such as the newly identified Middle East respiratory syndrome (MERS) coronavirus, which has infected 636 people since 2012 and has a death rate of about one in three. ${ }^{2}$ With an increasing number of cases being reported, fears exist that it could infect thousands of people, similar to the SARS (severe acute respiratory syndrome) coronavirus in 2002-03. ${ }^{3}$

The international response to MERS has been more rapid than to SARS at least partly because of global structures that have facilitated epidemiological assessment, international information sharing, and the development of potential treatments. In an increasingly interconnected and interdependent world, global rules negotiated among governments are crucial for facilitating international cooperation and for protecting the health of the world's population. Sometimes adhering to these rules requires governments to forgo some of their sovereignty and to trust an international organisation to act impartially and independently for the common good. One of the fundamental reasons for the creation of WHO in 1948 was to ensure that governments would "compromise their short-term differences in order to attain the long-run advantages of regularized collaboration on health matters."4

Although many global health problems can be dealt with outside of WHO, the negotiation, agreement, and monitoring of compliance with global health rules can realistically take place only in WHO's main decision making body, the World Health Assembly. WHO possesses unique political legitimacy because its membership encompasses all countries in the United Nations. This legitimacy allows WHO to convene governments and others (such as civil society, experts, and business) to negotiate rules, resolve differences, and reach consensus-all key elements of stewardship, a core function of the global health system. ${ }^{5}$

MERS exemplifies at least three areas of global rule making that are crucial for protecting global health: rapid information sharing on new infectious threats, fair arrangements for access to drugs and vaccines, and research and development of technologies and other interventions.

\section{Rules for information sharing on infectious disease}

MERS is just the most recent illustration of the fact that states acting in isolation cannot control the spread of infectious disease across their borders. Global collective action is vital not only to protect health but also to secure trade and human rights. Global rules can help ensure prompt identification and control of disease through an interconnected global network of information and surveillance.

The stature and impartiality of WHO is crucial to its success in monitoring and disseminating information. Countries need to trust an international agency to report and use health information impartially in the interests of public health. The revised International Health Regulations (2005) require states to report certain public health events of international concern to WHO and establish procedures that $\mathrm{WHO}$ and its members must follow to uphold global public health security. ${ }^{6}$ WHO member states adopted the regulations to balance their sovereign rights with a shared commitment to prevent the international spread of disease. 
The regulations require countries to strengthen their existing capacities for public health surveillance and response, while calling on higher income states to provide help with capacity building. Here again, WHO draws on its expertise to work closely with governments and partners to provide technical guidance and to mobilise the resources needed to implement the new rules effectively. The regulations do not include mechanisms to enforce compliance, and countries do not always fully or immediately report relevant data. But there are strong diplomatic and political pressures to conform to global rules, and each act of state compliance increases the normative force on other states to do the same.

\section{Rules for access to health technologies in pandemics}

More recently, WHO negotiated a highly contentious framework concerning the sharing of influenza viral samples and fair access to vaccines and treatments in the event of a pandemic. This was prompted by the Indonesian health minister's refusal to supply $\mathrm{H} 5 \mathrm{~N} 1$ virus samples to WHO Collaborating Centres for analysis and vaccine preparation in 2007, amid concerns about an outbreak of avian flu. She claimed that any vaccines or drugs derived from its viral samples were unlikely to be available to developing countries ${ }^{7}$ and invoked the principle of viral sovereignty to defend her decision to withhold samples until a more equitable system for access to vaccines in a pandemic could be established.

If developing countries were to withhold viruses from WHO Collaborating Centres, it would pose a threat to global health security and the ongoing risk assessment for influenza. After multiple tense negotiations, member states agreed the Pandemic Influenza Preparedness (PIP) Framework for the sharing of influenza viruses and access to vaccines and other benefits in 2011. Though imperfect, the agreement balanced the goals of improving and strengthening the sharing of influenza viruses with efforts to increase access to vaccines and other pandemic related supplies by developing countries. ${ }^{8}$ The framework was adopted at the 64th World Health Assembly.

In negotiating the PIP Framework and the International Health Regulations, WHO served as a respected international intermediary to set vital global rules. These achievements could happen only because of WHO's international legitimacy, impartiality, and technical independence. WHO also used its position to negotiate more equitable access to other drugs.

\section{Rules for generating innovation and access to medicines}

New research findings were recently published that identified a compound that could potentially protect humans from MERS and other coronaviruses by inhibiting their replication. ${ }^{9}$ While it is too early to draw conclusions on the effect of this discovery, it is a timely reminder of the central importance of research for global health. The 15 coauthors of the publication were based at academic institutions in the Netherlands, Switzerland, Sweden, and Germany, and the work was funded by research institutes based in Europe and Japan. Once their results were announced, they became a valuable global public good of potential use to governments, drug developers, and health workers not only in the Middle East but in all countries at risk of infection.

However, research and development for emerging infections and globally equitable access to drugs, vaccines, and diagnostics remains one of the most contentious issues in global health.
Although such technologies have the potential to prevent or treat deadly diseases, they also require costly investments in research and development.

In the past, the governments of wealthy countries and the multinational drug industry largely financed such investments, with patients ultimately reimbursing the costs by paying high prices for new medicines. With the globalisation of patent rules in the 1990s through the World Trade Organization (WTO) agreement on Trade Related Aspects of Intellectual Property Rights (TRIPS), it became easier for companies to charge high prices for medicines in developing countries. As a result, drugs were often priced at unaffordable levels and access to medicines became a sensitive political issue. Companies now sell some cancer drugs, for example, for prices as high as $\$ 70000$ ( $£ 42$ 000; $€ 52000)$ in India, where two thirds of the population live on less than $\$ 2$ a day.

Concern about access to drugs, which first drew global attention with the HIV/AIDS crisis, prompted governments to amend global norms on intellectual property. An addition to TRIPS in 2001 stated it "can and should be interpreted and implemented in a manner supportive of WTO Members' right to protect public health and, in particular, to promote access to medicines for all." ${ }^{10}$ This came after health ministers at WHO's World Health Assembly in 1996 insisted that health concerns be better incorporated into intellectual property rules. ${ }^{11}$

WHO was also instrumental in government negotiations to tackle shortcomings of the existing research and development system, which too often required difficult trade-offs between incentives for research (by keeping prices high) and ensuring widespread access (by keeping prices low). ${ }^{12}$ The 2008 Global Strategy and Plan of Action on Public Health, Innovation and Intellectual Property paved the way to explore new global rules for encouraging, financing, coordinating, and ultimately sharing the benefits of research and development. A WHO expert group in 2012 recommended that governments start negotiating such rules within a proposed global treaty. ${ }^{13}$ After yet another round of difficult negotiations at WHO, in May 2013 governments agreed to test new approaches to innovation that would pay for research and development with public funds, so that costs do not need to be recuperated through high prices. And at the 2014 World Health Assembly, governments agreed to establish a pilot international fund to finance research and development, mobilising public funds from countries across the income spectrum.

Once research and development has been paid for, drug prices can be set at the lowest possible levels (a concept known as de-linkage, as it breaks the link between high drug prices and research financing). WHO member states are now exploring international coordination mechanisms to improve the efficiency of global research by reducing duplication and providing incentives for rapid and open sharing of research findings, and they are testing out some of these principles in demonstration projects. $^{14}$

\section{WHO financing and stature}

As new challenges arise that threaten health security across the world, the independence and neutrality of WHO become even more important. But WHO is struggling. Its core budget, which was intended to provide guaranteed, long term, predictable financing through assessed contributions by all WHO member states, has atrophied. Powerful stakeholders are increasingly funding WHO through voluntary contributions, which now make up $80 \%$ of WHO's total budget. ${ }^{15}$ In 2013 , the Gates Foundation and the US and UK governments were the top three 
financial contributors to WHO. Roughly five sixths of UK funds and two thirds of US funds were channelled as voluntary contributions, which means the country has control over how it is spent. ${ }^{1}$ Top donors that channel a higher percentage of funds through core contributions are Japan, Germany, and France. Less wealthy countries rightfully question whether WHO has become an agent for powerful countries that have clear political incentives such as retaining tight control over the agency's priorities and operations for providing funding in this way. ${ }^{16}$

Because discretionary funding is given to disease specific causes rather than to cover core normative functions such as rule making the agency must plead with donor countries and organisations for needed resources. Voluntary funding, moreover, often is unconnected to the global burden of diseases. ${ }^{17}$ In addition, countries may choose to go entirely around the WHO through regional or small group bodies. ${ }^{18}$ For example, Brazil, Russia, India, China, and South Africa now convene an annual meeting of health ministers to strengthen cooperation on issues of shared interest among the five countries, such as technology transfer for medicine production and universal health coverage. ${ }^{19}$

Although WHO could benefit from additional resources, the greater challenge is that it needs a larger proportion of its budget guaranteed. The US made the prospect of financial stability within WHO virtually impossible by adopting a policy of zero nominal growth - a decline in real terms - for the core budget of UN agencies such as WHO in the 1999 Helms-Biden Act. Amending this law and similar provisions in other countries to allow an increase in the core budget is critical to strengthen the independence and neutrality of WHO and requires strategic advocacy to frame it as an important national security concern given the agency's importance in managing new disease outbreaks. ${ }^{20}$ Core funding has not yet received the attention it deserves in the US Congress and other national legislatures. In addition, countries in arrears should be further pressured to meet their financial obligations to WHO.

WHO is the only international agency that can broker global rules that protect the health of all, but is badly underfunded to perform this core function. The ongoing MERS outbreaks offer a critical opportunity to reform WHO financing so that it can perform its vital normative functions.

We thank Genevie Fernandes of the University of Edinburgh for research help and acknowledge insights gained from participation in the Chatham House high level working groups on WHO reform and sustainable financing convened by David Heymann, of which all four authors were members.
Contributors and sources: DS (@devisridhar) has published widely on international health institutions, health financing, and global governance. JF (@julio_frenk) served as minister of health of Mexico from 2000 to 2006 and was executive director of evidence and information for policy at WHO. LG (@LGostin) is the director of WHO's Collaborating Center on Public Health Law and Human Rights. SM (@SuerieMoon) has published widely on global governance and the political economy of global health. The article originated from discussions among the four coauthors about the comparative advantage of WHO. DS and SM wrote the first draft of the paper. JF and LG edited and commented on this draft. All authors approved the final version.

Competing interests: All authors have read and understood BMJ policy on declaration of interests and have no relevant interests to declare.

Provenance and peer review: Not commissioned; externally peer reviewed.

1 Clift C. What's the World Health Organization for? Chatham House, 2014.

2 World Health Organization. Middle East respiratory syndrome coronavirus (MERS-CoV)—update. Disease Outbreak News 2014. www.who.int/csr/don/2014_05 28_mers/en/.

3 Garrett L. Why MERS virus is so scary. CNN 2013 June 2. http://edition.cnn.com/2013/ 05/31/opinion/garrett-mers-virus/..

$4 \quad$ Allen C. World health and world politics. Int Organ 1950;4:27-43

5 Frenk J, Moon S. Governance challenges in global health. N Engl J Med 2013;368:936-42. Gostin L. Global health law. Harvard University Press, 2014.

7 Sedyaningsih ER, Isfandari S, Soendoro T, Supari SF. Towards mutual trust, transparency and equity in virus sharing mechanisms: the avian influenza case of Indonesia. Ann Acad Med Singapore 2008;73:482-8.

8 Kamradt-Scott A, Lee K. The 2011 pandemic influenza preparedness framework: global health secured or a missed opportunity? Polit Stud 2011;59:831-47.

9 Lundin A, Dijkman R, Bergström T, Kann N, Adamiak B, Hannoun C, et al. Targeting membrane-bound viral RNA synthesis reveals potent inhibition of diverse coronaviruses including the Middle East respiratory syndrome virus. PLoS Pathog 2014:10:e1004166.

10 World Trade Organization. Declaration on the TRIPS agreement and public health. WT/MIN(01)/DEC/2. 2001. www.wto.org/english/thewto_e/minist_e/min01_e/mindecl trips_e.htm.

11 't Hoen E. The global politics of pharmaceutical monopoly power. AMB Publishers, 2009:17.

12 Moon S, Bermudez J, 't Hoen E. Innovation and access to medicines for neglected populations: could a treaty address a broken pharmaceutical R\&D system? PLoS Med 2012;9:e1001218.

13 WHO Consultative Expert Working Group on Research and Development: Financing and Coordination. Research and development to meet health needs in developing countries: strengthening global financing and coordination. WHO, 2012.

14 Rottingen J, Moon S, Tangcharoensathien V. Multistakeholder technical meeting on implementation options recommended by the WHO consultative expert working group on in 2012

15 Sridhar $\mathrm{D}$. Who sets the global health research agenda? The challenge of multi-bi financing. PLoS Med 2012;9:e1001312.

16 Sridhar D, Woods N. Trojan multilateralism: global cooperation in health. Global Policy 2013;4:325-35.

17 Nozaki I. WHO's budgetary allocation and disease burden. Lancet 2013:382:937-8.

18 Woods N, Betts A, Prantl J, Sridhar D. Transforming global governance for the $21 \mathrm{st}$ century. UNDP Human Development Report Office, 2013. http://hdr.undp.org/sites/default/ files/hdro_1309_woods.pdf.

19 Barbosa da Silva J, Desiraju K, Matsoso P, Minghui R, Salagay O. BRICS cooperation in strategic health projects. Bull World Health Organ 2014;92:388.

20 Mackey TK, Novotny TA. Improving United Nations funding to strengthen global health governance: amending the Helms-Biden agreement. Glob Health Gov 2012;VI.

Cite this as: BMJ 2014;348:g3841

๑ BMJ Publishing Group Ltd 2014 


\section{Key messages}

Recent outbreaks of MERS highlight the need for a global response to infectious disease

WHO has had a crucial role in developing rapid information sharing on new infectious threats and fair arrangements for access to drugs and vaccines and to research and development

WHO is the only international agency that can broker such global rules but is badly underfunded to perform this core function

The MERS outbreaks offer an opportunity to reform WHO financing 